
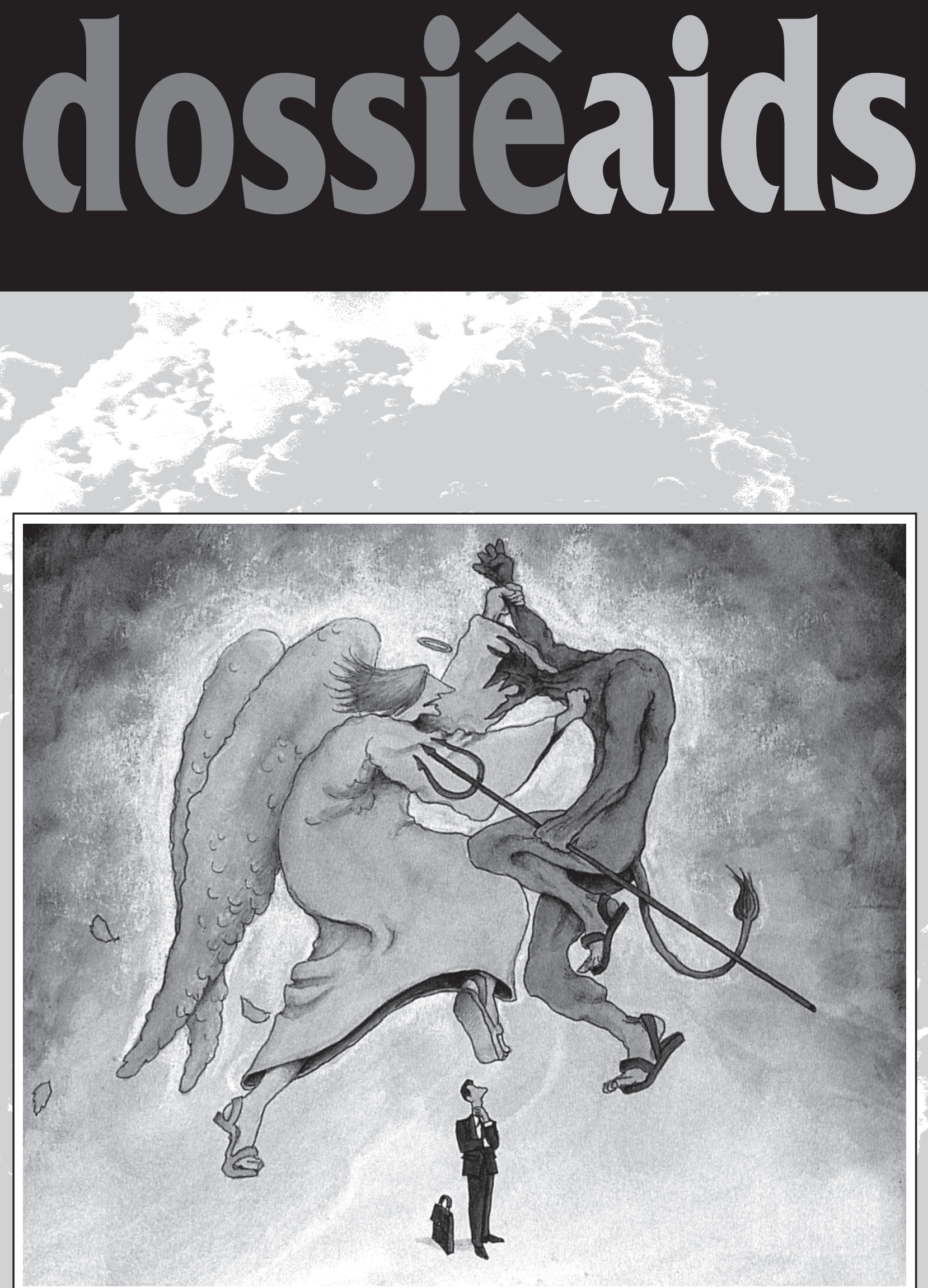

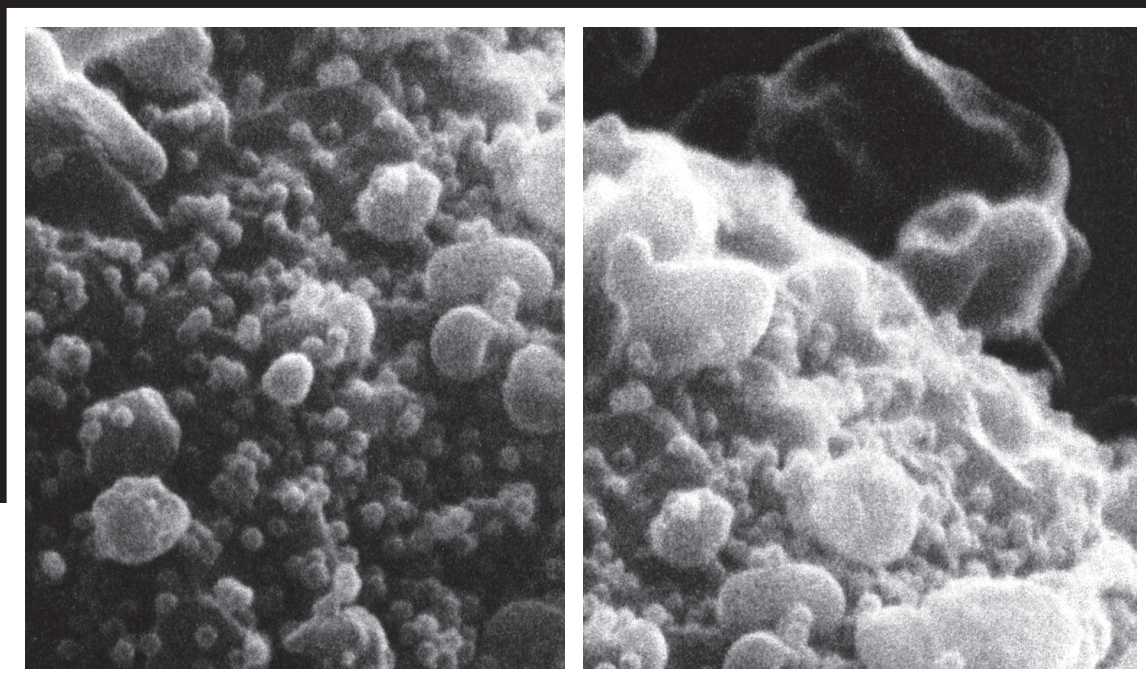

TERESA ANCONA LOPEZ

\title{
Aids e o Direito Civil brasileiro
}

\author{
CONSIDERAÇÕES GERAIS. A CIDADANIA. \\ OS CIDADÃOS DOENTES. PROTEÇÃO JURÍDICA
}

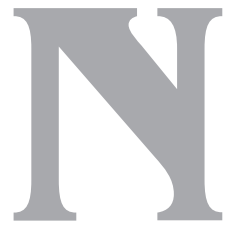

a verdade, não haveria necessidade de um estudo específico sobre os direitos e deveres do aidético dentro da ordem jurídica, porquanto são eles os mesmos de todo e qualquer cidadão.

O princípio basilar que rege a matéria se encontra na Constituição Federal de 1988, que repete todas as outras constituições anteriores, e que é consagrado no mundo inteiro. No artigo 5으, caput, da Carta Magna vem determinado que: “Todos são iguais perante a lei, sem distinção de qualquer natureza, sendo invioláveis o direito à vida, à liberdade, à igualdade, à segurança e à propriedade".

TERESA ANCONA LOPEZ é professora do Departamento de Direito Civil da Faculdade de Direito da USP. 
Portanto, ao tratarmos dos problemas jurídicos que envolvem os portadores de HIV/Aids, estaremos, mais uma vez, enfrentando a questão da proteção que o Direito deve dar a todo cidadão doente ou sadio e que tenha seus direitos ameaçados ou, ainda com maior razão, violados.

Porém, de outro lado, peculiaridades jurídicas existem tendo em vista as características de tal tipo de doença, que, além de gravíssima, foi classificada pela OMS como epidemia ou até pandemia (classificação discutível) e, como se não bastasse, é a mais estigmatizada das doenças, sofrendo o portador e sua família os mais variados tipos de preconceitos e rejeições. É necessário lembrar que no passado, quando não se sabia que tipo de doença era o câncer e se transmissível ou não, o preconceito era praticamente o mesmo, sendo de recente memória o medo que as pessoas tinham de chegar perto do doente e mesmo do morto em seu velório. Hoje ainda persistem estigmas contra os hansenianos, tuberculosos e sifilíticos, apenas para exemplificar.

Esse preconceito que pode existir até dentro da própria família cria situações tristes como a dos filhos adultos aidéticos que, não conseguindo trabalhar, ou por fraqueza física ou, na maioria das vezes, por discriminação, são obrigados a ajuizar ações de alimentos contra os pais que os deixaram em total abandono.

De outro lado, evidentemente, também as pessoas que foram contaminadas ou por via sexual ou por transfusões de sangue têm seus direitos e ressarcimentos garantidos pela ordem jurídica.

Dessa forma, os culpados por tais contaminações deverão responder civil e penalmente, e como a responsabilidade civil é independente da penal, mesmo que os responsáveis tenham sido absolvidos no juízo criminal (homicídio doloso ou culposo, crime de periclitação da vida e da saúde, crime de perigo de contágio de moléstia grave), poderão vir a responder por danos materiais e morais à vítima do contágio ou à

sua família.
DIREITOS DA PERSONALIDADE E DIREITOS HUMANOS DO AIDÉtICO. SUA VIOLAÇÃO. DANO MORAL POR RICOCHETE

A expressão direitos da personalidade designa o conjunto de direitos consagrados pela ordem jurídica que têm por conteúdo bens inerentes a cada pessoa, durante toda sua vida e mesmo depois de sua morte.

Segundo R. Limongi França, em definição já clássica, direitos da personalidade são as "faculdades jurídicas cujo objeto são os diversos aspectos da própria pessoa do sujeito, bem assim de sua projeção essencial no mundo exterior" (1).

Os direitos da personalidade são os direitos humanos privados. Os direitos humanos públicos são os direitos fundamentais subjetivos e devem ser reconhecidos a todas as pessoas pelo simples fato de existirem.

A Constituição Federal de 1988 (art. 5o, incisos V e X) consagrou dentro do capítulo dos direitos e garantias fundamentais os direitos do homem em seus dois aspectos: o público e o privado. Veio preencher grave lacuna legislativa além de alçar a normas constitucionais os direitos da personalidade, assegurando, inclusive, o pedido de indenização por dano moral e material decorrente de sua violação.

Dessa forma, o aidético, como cidadão, pode fazer valer os seus direitos fundamentais quer públicos, quer privados, como o direito à vida e à saúde, que se colocam em primeiro lugar. Dentro desses está o direito ao tratamento médico, incluindo o uso de medicamentos que aumentem sua sobrevida, como o chamado "coquetel de drogas".

A discussão sobre a distribuição desses medicamentos pelos governos deverá se tornar obrigatória, pois, como é do conhecimento geral, pouquíssimas pessoas no mundo poderiam arcar com seus custos. E é através de tratamentos cada vez mais evoluídos que veremos o aidético se transformar em doente crônico, como outro qualquer, e com qualidade de vida.

O direito ao sustento também é direito
"Aspectos Jurídicos da Aids", in $R T 661 / 13,1990$. 
fundamental, que deve ser suprido pelos parentes mais próximos, quando o aidético não puder trabalhar ou for discriminado, como já falamos. Sempre caberá ação de alimentos, havendo necessidade de um lado e possibilidade de fornecimento do outro.

Os direitos da personalidade mais comumente atingidos pelo portador $\mathrm{HIV/}$ Aids são: o direito à intimidade, à vida privada, imagem e honra, no sentido de dignidade. Todos esses direitos são facilmente violados pelos parentes, "amigos", colegas de trabalho, patrão, médicos, etc., e quando o doente é famoso é a mídia que se encarrega de espalhar a notícia.

Nessa última hipótese temos o confronto entre o direito à informação, que tem o público em geral, e o direito à imagem e à honra, que têm o doente e sua família. Cada vez mais a informação acaba ganhando a contenda. Lembrem-se os casos do músico brasileiro Cazuza e do ator americano Rock Hudson.

Os danos causados são principalmente morais, o que não exclui também a possibilidade de prejuízos patrimoniais, principalmente no que diz respeito ao trabalho do aidético. Claro que nesse caso a discriminação também deve ser punida.

O dano ao portador do vírus também pode atingir seus parentes, cônjuge ou companheiro de união estável (hoje perfeitamente cabível), que terão legítimo interesse de agir pedindo ressarcimento por danos morais e mesmo materiais. É o que se chama de dano moral reflexo (também há possibilidade de dano material reflexo) ou por ricochete porque nasce de dano a terceiro. "Dano por ricochete é aquele que tem por fato gerador a lesão ao interesse de uma terceira pessoa: é conseqüência do evento danoso. Trata-se aqui, também, de um interesse próprio" (2).

Dado o caráter da doença os direitos ao recato e à privacidade da família vêem-se totalmente violados. Muitas vezes esse sigilo é quebrado pelos médicos. Mais adiante veremos quando é legítima essa comunicação.

Penso que nos casos de dano moral por ricochete tanto caberá o pedido quando se tratar de violação aos direitos da personalidade - dano moral objetivo - como no caso do dano moral que se traduz em angústias e sofrimentos, pretium doloris. Trata-se do dano moral em sentido subjetivo ou dano moral stricto sensu, que muitos não admitem, por ser de difícil prova. O desrespeito ao doente com reflexos em sua família pode existir estando ele vivo ou morto.

Apenas para registar, lembramos que hoje, depois do aparecimento da Aids, reavivou-se a discussão sobre a eutanásia que agora aparece nas modalidades de morte digna e de suicídio assistido. Problemática que envolve o conceito de direitos da personalidade mas que, além de depender da
Sérgio Severo, Os Danos Extrapatrimoniais, São Paulo, Saraiva, 1996, p. 22

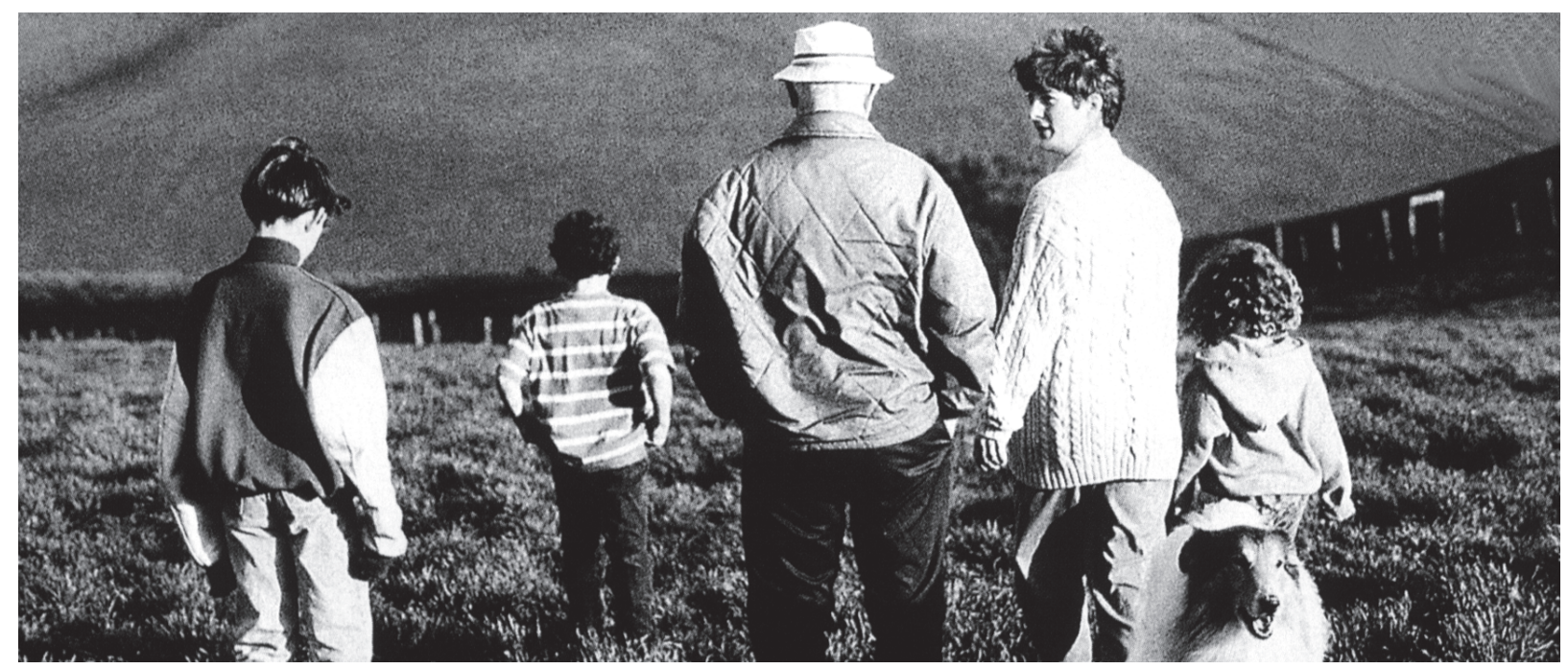


aprovação pelo Estado, tem como centro dos debates a religião e a moral.

\section{A CAPACIDADE CIVIL E O AIDÉTICO. INTERDIÇÃO}

O problema da capacidade jurídica do aidético tem surgido amiúde na prática, porquanto, principalmente em fase terminal, o portador do vírus pode ter seus neurônios afetados, com modificações de seu entendimento e discernimento, o que acaba se refletindo no uso de sua vontade, tendo em vista sua participação em negócios jurídicos, como declarações em contratos, testamentos e, principalmente, a livre administração de seu patrimônio. Nesses casos vão ser aplicadas as regras gerais que regem a matéria das incapacidades e, dessa forma, o fato de a pessoa estar com Aids não impede a participação na vida negocial, pois a doença por si só não a torna incapacitada para isso. Somente quando suas faculdades mentais estiverem alteradas é que se colocará o problema de sua capacidade jurídica.

Caso se agrave seu estado psíquico poderá sofrer processo de interdição, depois de feitas as devidas perícias médicas e com nomeação de curador.

E os atos jurídicos praticados pelo aidético que estava fora de suas faculdades mentais poderão ser anulados? Tudo vai depender da data da sentença de interdição, que somente declara a incapacidade. A diferença de situação entre o incapaz interditado e o não-interditado está na matéria de prova, desnecessária se houve interdição e necessária se não houve (3).

Os intervalos lúcidos não terão a menor importância se o doente estiver interditado e portanto sem capacidade civil, sendo representado por seu curador. Poderão, ao contrário, ter consequiências sérias se o incapaz não tiver sido interditado, pois aferevedo, Negócio Jurídico e Declaração Negocial, São Paulo, 1986, p. 113

4 Repertório IOB de Jurisprudência no I5/93, p. 287 co na prática, pois é comum doentes de Aids deixarem, através de testamento, seus bens para um amigo, um companheiro ou mesmo para seus médicos, em detrimento de seus familiares.

\section{CASAMENTO, UNIÃO ESTÁVEL, PROLE EVENTUAL E PORTADORES DO VÍRUS HIV/AIDS. O PEDIDO DE INDENIZAÇÃO POR CONTAMINAÇÃO ENTRE CÔNJUGES E COMPANHEIROS}

No Brasil não existe obrigatoriedade de exame pré-nupcial, portanto fica a critério das partes decidir sobre sua necessidade ou não. Dessa forma, pode ser pedida a anulação de casamento com portador do vírus com fundamento no art. 219, III, do Código Civil, por se tratar de moléstia grave transmissível por contágio ou herança e capaz de pôr em risco a saúde do outro cônjuge ou dos filhos. Todavia, exige o citado dispositivo, que é taxativo, que a moléstia grave seja anterior ao casamento, requisito hoje que, com certeza, também deverá ser aplicado à relação concubinária.

O fato de o cônjuge doente ignorar ser portador do vírus da Aids (ou de qualquer moléstia grave) não ilide a aplicação da norma, desde que esse contágio tenha se dado antes da união. Apesar de alguns juristas e também decisões jurisprudenciais entenderem o contrário, ou seja, que se o portador casou na ignorância do mal, o casamento deverá ser mantido. Posição com a qual não concordamos, porque a finalidade da lei em exame é a proteção à saúde do outro cônjuge e de sua descendência. Nesse sentido, temos acórdão da $2^{-}$C. Civil do TJRJ (4) que anulou casamento com portador de Aids por ser doença grave e transmissível adquirida anteriormente ao casamento apesar de ignorada pelo cônjuge doente. Nesse caso foi salientado o risco de a apelante contrair a doença.

O erro a que se refere o art. 219 do Código Civil diz respeito a um engano a que foi induzido o declarante até por cir- 
cunstâncias aparentemente diferentes da verdadeira.

No caso específico do vírus HIV há pessoas que pela vida que levaram até então (recebeu transfusão de sangue, sexo promíscuo ou drogas) têm consciência de que talvez sejam portadoras do vírus da Aids. Se não fazem exame e não comunicam ao futuro cônjuge sua dúvida estão agindo com reserva mental, com carga de má-fé, e deverão responder por isso.

No caso da Aids adquirida após o casamento temos que examinar o modo através do qual se deu esse contágio. Se através de transfusão de sangue ou picadas com material infectado, evidentemente nada poderá ser feito, nem a separação ou o divórcio, pois foge aos motivos da lei. O art. 5º, caput, da Lei 6.515/77, exige que a separação seja fundada ou em conduta desonrosa ou na violação grave dos deveres do casamento e ao mesmo tempo que essa violação torne a vida comum insurportável. O par. $2^{\circ}$ do mesmo artigo somente permite a separação judicial quando o outro cônjuge estiver acometido de grave doença mental, manifestada após o casamento, mesmo assim somente quando a enfermidade durar cinco anos com cura improvável. Outra, evidentemente, será a situação se a moléstia foi adquirida exatamente pelos outros meios de contágio (sexo e drogas), quando os moti- vos são mais do que suficientes para o pedido. Claro que sempre dependerá da prova de todos os requisitos legais feita pelo cônjuge que pediu a separação, principalmente da data da contaminação.

Nesse ponto o problema se complica pois é matéria de difícil prova. Imaginemos que o casal de noivos faz os exames pré-nupciais e nada de anormal aparece. Depois de um ou dois anos um dos cônjuges apresenta sintomas de Aids. Sendo que a Aids pode se manifestar logo depois da contaminação até dez anos em média, não se saberá quando se deu o fato acarretador da doença. Todavia, ao serem feitos os exames, o portador poderia estar no primeiro período de latência da doença, quando durante duas semanas a três meses após o contágio os resultados são negativos, o que é chamado de "janela imunológica" ou falso negativo. No estágio atual da medicina não há como ser diferente. Excepcionalmente, segundo literatura especializada, essa "janela" pode chegar a 2, 3 ou 4 anos.

Como provar que a doença era anterior ao casamento?

Poderá, de outro lado, haver em qualquer caso pedido direto de divórcio, fundado no art. 40 da mesma lei, por decurso de prazo de dois anos de separação de fato comprovada e sem invocação de qualquer dos motivos do art. $5^{\circ}$, pois o par. $1^{\circ} \mathrm{do}$ art.

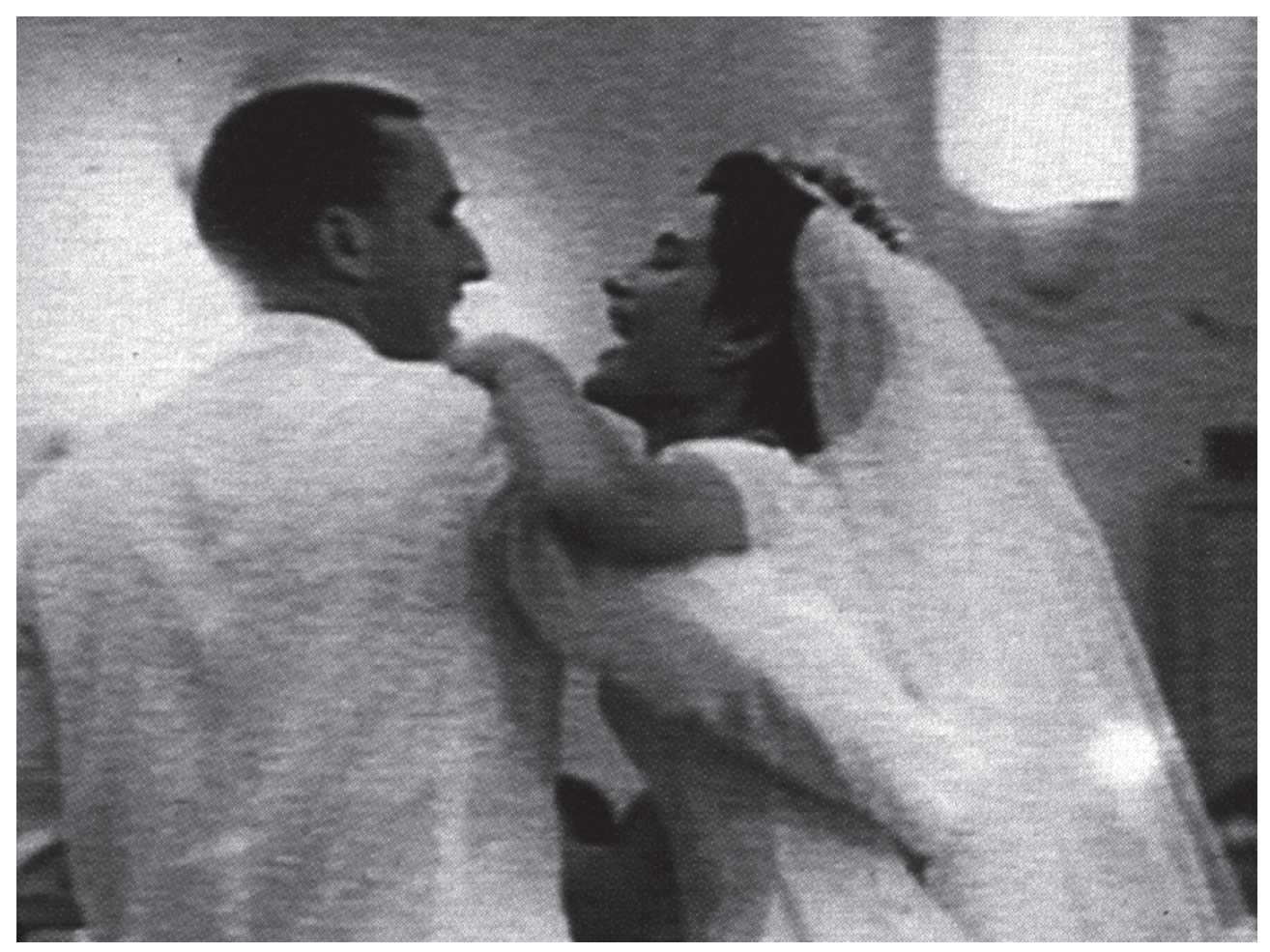


40 foi expressamente revogado pela Lei 7.841, de 17/10/89. Evidentemente, a separação consensual ou por mútuo consentimento sempre será possível, desde que casados há mais de dois anos; porém, a separação de corpos é possível a qualquer tempo.

Visa-se com todas essas leis a proteção da saúde do outro cônjuge e da prole do casal, nunca perseguir ou estigmatizar o doente. Cabe lembrar que os direitos do nascituro são protegidos desde a concepção (art. 4oㅡ, última parte, Cód. Civil), estando, portanto, aí incluídos todos seus direitos, desde o direito ao nome e aos benefícios patrimoniais, até principalmente o direito à vida e à saúde. Dessa forma, o aborto de nascituro supostamente contaminado por Aids não é permitido no Brasil,

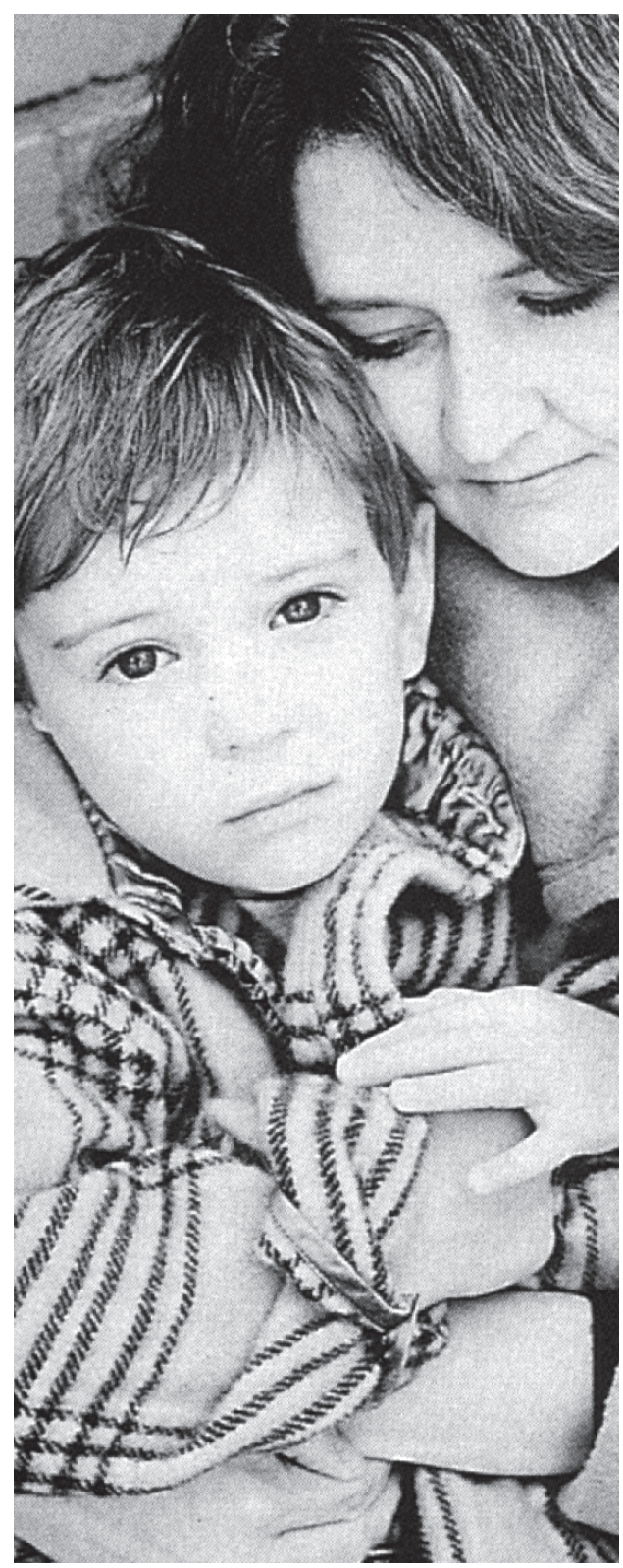

sendo crime definido no Código Penal.

Interessante é a possibilidade do pedido de danos morais (imprescritíveis) por pessoa adulta, que é portadora de Aids desde o ventre materno, ou por sua mãe ter sido contaminada por sangue infectado ou por sua contaminação direta quando pequeno em hospital. A prova nesses casos é muito difícil devido ao lapso de tempo passado. Na maioria das vezes não se consegue provar o nexo causal entre a transfusão e a Aids, porque há outras maneiras de adquiri-la (5).

A respeito do contágio através de vírus HIV em casal que vive em união estável ou concubinato podem ser tomadas várias medidas jurídicas, como o pedido, através de ação cautelar, de separação de corpos e retirada do companheiro aidético do lar. Também na união estável cabe hoje a discussão sobre o descumprimento dos deveres dos conviventes, ou seja, respeito e consideração mútua, assistência moral e material recíproca, guarda, sustento e educação dos filhos (arts. 1ํ e 2o da Lei 9.278/ 96). No mesmo sentido, projeto de união estável em tramitação no Congresso. Além disso, caberá indenização por perdas e danos materiais e morais ao doente ou ao espólio, no caso de seu falecimento.

A responsabilidade civil exige prova de culpa (imprudência, negligência ou imperícia) ou dolo (ânimo de prejudicar). Dessa forma, age com culpa toda pessoa que, sabendo ser portadora do vírus HIV ou mesmo só tendo dúvidas sobre a possibilidade de ser portadora do vírus, mantém relações sexuais sem tomar os cuidados necessários ou avisar o parceiro.

No caso trata-se de culpa grave e em Direito Civil a culpa grave ao dolo se equipara. Como bem explica Carlos Roberto Gonçalves (6) a culpa, nesse caso, corresponde ao dolo eventual, pois está o doente assumindo, conscientemente, o risco da transmissão.

Também lembra o mesmo autor que há em alguns casos a culpa concorrente da vítima e, havendo dano, a indenização deverá ser reduzida proporcionalmente.

Recente decisão do Tribunal de Justiça 
de São Paulo (7) considerou culpado o companheiro em relação concubinária, concedendo à vítima contagiada durante o concubinato indenização por danos materiais e morais. Foi excluída a culpa concorrente da autora porque não houve de nenhuma forma meios de perceber sequer indícios de conduta desregrada do concubino. Na cumulação dos danos morais e materiais houve verba também por indenização de serviços especiais prestados ao doente até a morte, tendo, inclusive, para tanto, deixado seu emprego fixo.

E no casamento desfeito no qual um dos cônjuges era aidético também caberá o pedido de perdas e danos?

Matéria delicada e da qual muito pouco se tem notícia é essa do dano moral em separação e divórcio. Em princípio o Direito brasileiro se contenta em apenar o cônjuge culpado apenas impondo-lhe o encargo alimentar e decretação da separação. Pensamos que havendo culpa e dano haverá lugar para indenização por danos materiais e morais.

Se a concubina ou até a namorada podem pedir indenização se foram seviciadas, aleijadas e mesmo contagiadas, por que a ex-mulher ou ex-marido não poderão pedir tal indenização?

Sem dúvida, contaminar o cônjuge com doença gravíssima é crime e também é ato ilícito civil. Sobre o tema há importante artigo do advogado José de Castro Bigi (8) no qual está demonstrada muito bem a possibilidade dessa indenização. Para tanto, mostra argumentos de muitos juristas entre os quais Mário Moacyr Porto, Caio Mário da Silva Pereira, Yussef Said Cahali e o voto vencido do desembargador Athos Gusmão Carneiro no Tribunal de Justiça do Rio Grande do Sul.

Caio Mário da Silva Pereira é claro ao afirmar que "afora os alimentos, que suprem a perda da assistência direta, poderá ainda ocorrer a indenização por perdas e danos (dano patrimonial e dano moral) em favor do cônjuge inocente". E Yussef S Cahali, em seu Divórcio e Separação, ensina que "o cônjuge responsável responde ainda cumulativamente pelo prejuízo à saú- de do cônjuge agredido nos termos dos arts . 159 e 1.539 do Código Civil, sem prejuízo das sanções penais".

\section{TRATAMENTO DA AIDS. EPIDEMIA. PLANOS DE SAÚDE. CÓDIGO DE DEFESA DO CONSUMIDOR}

O direito à saúde que integra o direito à vida é sem dúvida o mais desrespeitado em nosso país. A Constituição Federal o define como um dos direitos sociais no art. 196 no qual está declarado que a saúde é direito de todos e dever do Estado, sendo que em seu art. $1^{\circ}$ já vinha determinado que são fundamentos do Estado democrático, entre outros, a cidadania e a dignidade da pessoa humana.

O que dizer da aplicação de todos esses princípios ao problema do aidético e seu tratamento?

Como sabemos, o Estado não consegue cuidar dignamente de todos os seus doentes sejam aidéticos ou não e então delega tacitamente tal tarefa aos vários tipos de planos de saúde que aceitam prazerosamente o encargo, porquanto muito lucrativo. Basta observar o número crescente de planos e atrativos para chamar clientes.

Todavia, os planos só funcionam perfeitamente para os que têm saúde (claro, são planos de saúde!...). Os que mais necessitam, como os doentes crônicos, os que têm moléstias degenerativas e também os portadores de doenças infecto-contagiosas, como a Aids, são ardilosamente afastados através de cláusulas contratuais e novas interpretações jurídicas de institutos do direito privado.

Continuamos até o momento na luta de braço-de-ferro entre doentes e planos e na qual são chamados o Procon (os planos são campeões de queixas perante o órgão) e o Judiciário. Sem eles o doente morre na rua.

No caso da Aids os planos (convênios, seguros) alegam não ter capacidade econômica (podem falir...) de absorver os doentes portadores do HIV, em primeiro lugar porque é uma epidemia, e as epidemias estão

\footnotetext{
10 C. D. Privado, 23/4/96 Boletim AASP, no 1.965, p. 266

8 RT 679/46.
} 
9 RT 728/267; IOB nㅇ 7/92, P. 138

I0 RT 728/267; RT 731/290; RT 732/268: IOB n- 7/92, abril/ 92, p. 138

|| Boletim AASP no 1.982, 24/12

12 9a C. C. TJSP, 9/2/95, in $10 B n^{\circ}$ $\mid 6,2$ a quinzena de 95, p. $25 \mid$

13 | 4․ㅡ C. TJSP, |ㅇ| |/94, in RT $7 / 2 / 155$

| 4 RT725/233, 9a C. C. TJSP, I0/ $8 / 95$.

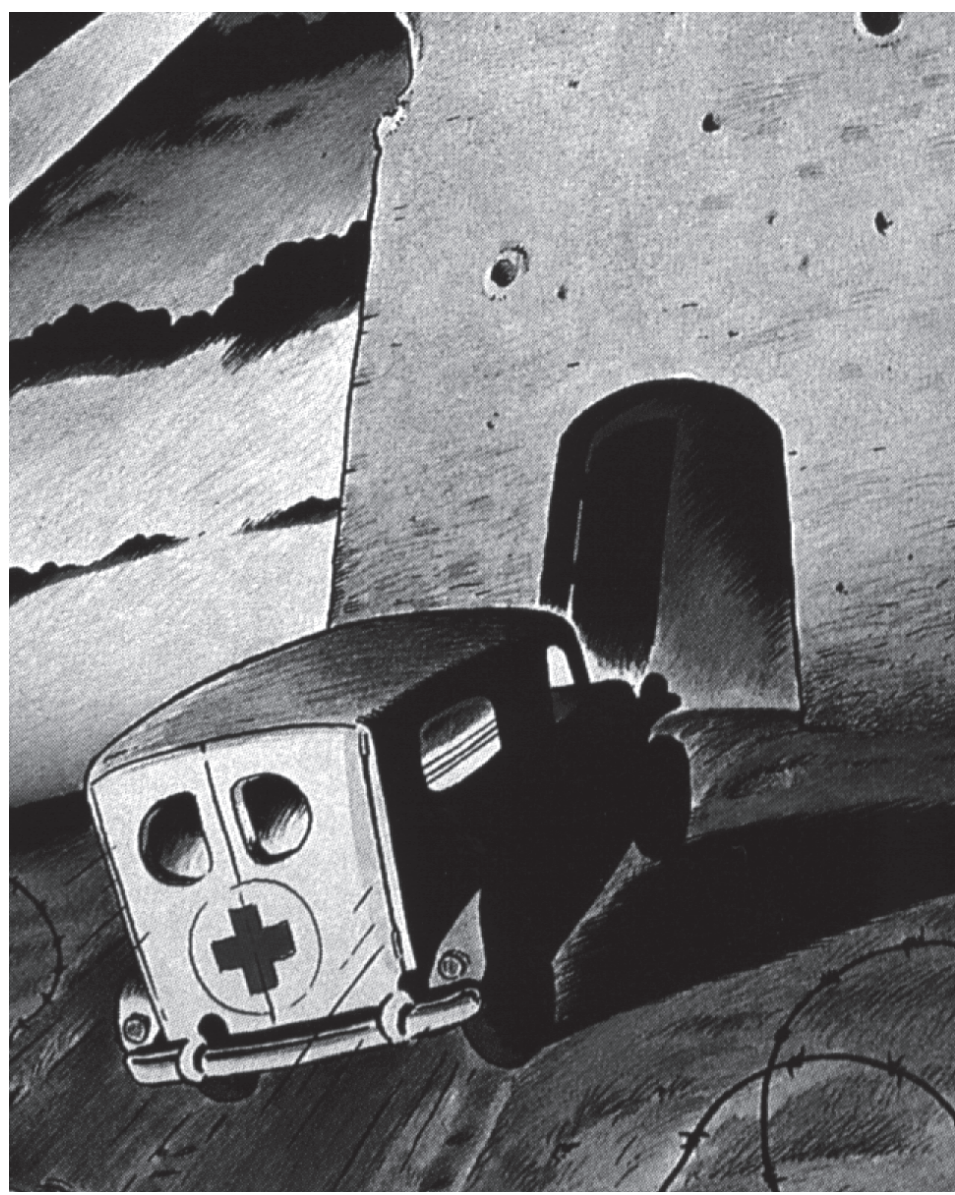

excluídas do ritmo normal de atendimentos, e, em segundo lugar, porque os gastos com os aidéticos são altíssimos. Mesmo os planos que davam cobertura expressa à Aids alegaram epidemia e aplicaram a teoria da imprevisão e a cláusula rebus sic stantibus, ou seja, como houve aumento imprevisto do número de doentes deveria haver revisão dessa cláusula contratual. Esses argumentos não foram bem-sucedidos perante o Judiciário (9).

A jurisprudência tem tentado resolver esse impasse ora com apoio no Código de Defesa do Consumidor, aplicando as normas sobre contrato de adesão e cláusulas abusivas, ora redefinindo o que seja epidemia (ilustraremos adiante) e doenças infecto-contagiosas, sempre tendo em vista a proteção ao doente.

As decisões no caso de o portador esconder seu mal em geral dão ganho de causa à seguradora, pois houve má-fé ao subscrever a proposta (10), outras vezes, o segu-

rado ganha a ação porque a empresa que explora plano de saúde e recebe contribuições sem submetê-lo a exame não pode escusar-se ao pagamento da contraprestação (11).

Sobre os vários acórdãos que discutem o verdadeiro alcance do conceito de epidemia temos aquele que decidiu que a moléstia adquirida pelo vírus HIV não se configura epidemia, pois essa vem definida como "surto de doença contagiosa que ataca numerosas pessoas ao mesmo tempo" (Silveira Bueno, Dicionário Escolar), também “doença que surge rápida num lugar e acomete simultaneamente grande número de pessoas" (Dicionário Aurélio). E segundo a mesma decisão a moléstia é lenta em sua evolução, só alcançando determinado número de pessoas e que pertençam a um grupo da sociedade, incluindo os hemofílicos, que têm risco de contágio, concluindo que não alcança indiscriminadamente a generalidade do grupo social, o que descaracteriza uma epidemia (12).

Outra decisão declara que não pode o plano de saúde escusar-se da obrigação de prestar ao portador do vírus HIV o tratamento prometido valendo-se da cláusula genérica de exclusão (enfermidades ou lesões causadas por epidemias). E continua: "seja como for ainda que se possa considerar a Aids tecnicamente epidêmica [grifo nosso], como o quer o convênio, essa cláusula constitutiva de contrato de adesão, unilateralmente imposta pelo plano de saúde, deve ser, por isso, interpretada de maneira mais favorável ao conveniado" (13). E finalmente declara outro acórdão que a posterior conceituação da Aids como epidemia pela OMS e outras entidades não autoriza modificar a interpretação contratual. O contrato, na dúvida, há de ser interpretado contra o estipulante de seus termos (14).

A lei que mais protege os conveniados é o Código de Defesa do Consumidor, sendo que depois de sua promulgação melhorou muito a situação dos aderentes a planos de saúde. São importantes, além de toda a sua principiologia, as regras que fulminam de nulidade as cláusulas abusivas, princi- 
palmente art. 51 , par. 1ํ. Também devem ser lembrados os dispositivos sobre a propaganda enganosa (art. 37), importantes nesse contexto. Sem nos esquecer do art. $3^{\circ}$, par. 2o que define serviço como "qualquer atividade fornecida no mercado de consumo, mediante remuneração, inclusive as de natureza bancária, financeira, de crédito e securitária, salvo as decorrentes de caráter trabalhista".

Qual a solução para toda essa situação?

A primeira saída é a promulgação de lei obrigando expressamente os planos de saúde a cobrirem toda e qualquer doença, tendo em vista a precariedade do sistema público.

Outra alternativa seria fazer seguros para todas as doenças com "franquia", ou seja, o doente sempre terá de arcar com uma parte. Se esse sistema dá certo para seguro de automóveis, por que não dará para seguro-saúde? É o sistema adotado em muitos países, principalmente nos EUA.

Problema grave e de difícil solução em todos os países do mundo é o que se refere à compra de medicamentos, como o atual "coquetel de drogas" que aumenta significativamente a vida do aidético. A única saída é obrigar o Estado a fornecer as drogas.

\section{TRANSFUSÕES DE SANGUE. CONTAMINAÇÃO. JANELA IMUNOLÓGICA. RESPONSABILIDADE CIVIL DOS HOSPITAIS E BANCOS DE SANGUE}

O sangue contaminado sempre existiu Nenhuma transfusão de sangue é totalmente segura até hoje. Não é incomum pessoas perderem a vida porque receberam sangue contaminado com vírus da hepatite ou da malária, principalmente no pós-operatório, quando o paciente se acha em situação débil e delicada. Com o aparecimento da Aids instalou-se o pânico entre as pessoas obrigadas a receber transfusões.

Esse quadro ainda é mais preocupante quando o doador já contaminado faz os testes e nenhum sinal do vírus aparece. Isso é perfeitamente possível em diversas mo- léstias e é o que também acontece com as contaminações por vírus HIV. Isso se dá no período da "janela imunológica", quando podemos ter os exames "falsos negativos".

É possível imaginar a angústia de alguém que recebeu sangue em transfusão e depois é comunicado que talvez aquele sangue estivesse contaminado porque seu doador só tempos mais tarde apareceu com Aids. Apenas essa dúvida que infunde grave temor de dano e grandes sofrimentos já constitui motivo suficiente para pedido de dano moral.

O sofrimento dessas pessoas tem base real, elas não estão exagerando, nem fantasiando, pois, segundo relatos científicos, na verdade o vírus HIV-1 tem dois períodos de incubação: o primeiro vai da data da aquisição do vírus até a soroconversão, sendo chamado período de janela (sometimes called window). Este é o período mais perigoso, porque incerto. $\mathrm{O}$ segundo período vai do ponto em que se descobre a soropositividade até o aparecimento da doença, a Aids propriamente dita.

Dessa forma, a verdadeira data da infecção é raramente conhecida. O lapso de tempo do período da "janela” até a certeza da reação sorológica positiva, $\mathrm{HIV}+$, é aproximado. Em média de duas semanas a três meses e raramente mais de sete meses. Em raríssimos casos pode chegar a 42 meses, o que constitui uma exceção (15).

Em publicação brasileira aparecem os dados sobre o que estamos falando: uma em cada 40 mil transfusões de sangue testado como negativo pode transmitir o vírus. Adverte-se que pessoas que admitam a possibilidade de estar infectadas devem negar-se terminantemente a doar sangue (16).

Tendo em vista essa situação em que medida os hospitais e hemocentros são responsáveis pelo sangue que aplicam?

Diante do atual estágio da ciência não há sangue $100 \%$ seguro. Dessa forma o risco sempre existirá e esse risco trabalha a favor de médicos e hospitais e contra o receptor de sangue. Eé por causa de todo esse raciocínio que algumas correntes jurídicas tentam proteger os bancos de sangue e hospitais.
15 The Epidemologic Reviews, vol. 15, no 2, John Hopkins University School of Hygiene and Public Health, 1993.

16 Drauzio Varella et alii, Aids Hoje, 1989. 
Porém, de outro lado, toda atividade perigosa ou que cria riscos à população em geral está sujeita a responder objetivamente tanto mais que os riscos são compensados pelos altos lucros dessas atividades. Não pode a população ficar na dependência da prova de culpa do hospital ou banco de sangue. Havendo nexo causal entre transfusão e contaminação com HIV+ haverá lugar para indenização. O hospital poderá demonstrar ou que o doente já estava contaminado (através de exames feitos sem autorização do paciente) ou que foi contaminado depois e de outra forma, enfim é matéria de prova.

Nessa questão aplica-se o art. 14 do Código de Defesa do Consumidor, que adota a teoria objetiva sobre a responsabilidade do fornecedor de serviços que causem danos aos consumidores. Alguns doutrinadores ilidem a responsabilidade pelas transfusões contaminadas, pois, no dispositivo citado, têm que ser levadas em consideração circunstâncias relevantes ao serviço defeituoso, ou seja, ao se apreciar o dano produzido por uma transfusão devese levar em conta "o resultado e os riscos que razoavelmente dela se esperam”. Em outras palavras, no estágio atual da ciência médica não é possível termos um sangue

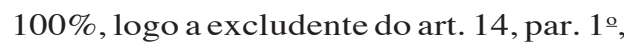
II se aplicaria aos fornecedores de sangue. Não seria admitir que o doente sempre arcasse com o risco?

Todavia, a jurisprudência, sempre no intuito de proteger a parte mais fraca, tem responsabilizado hospitais e hemocentros pelo sangue contaminado. A respeito dessa questão há decisão em que foi responsabilizado hospital por contaminação em recém-nascido com vírus da Aids, por ter sido usado sangue diverso do doado pelo pai da criança (17).

Fato que também é causa de pedido de indenização por dano moral é o fornecimento de resultado errado de exame para detectar o HIV, são os chamados "falsos positivos", que causam sofrimentos profundos nas pessoas vítimas desse erro. É o o hospital que, após realização de exames destinados a determinar se doador de sangue está infectado com vírus da Aids, apresenta-lhe três resultados, um positivo, outro duvidoso e um terceiro indeterminado, verificando, depois, que o resultado correto, obtido em outro centro de saúde, é o negativo, padecendo o paciente enquanto durou a dúvida, grande dor, muito sofrimento, tristeza, mágoa e vergonha" (18).

\section{VIOLAÇÃO DO SIGILO MÉDICO. RESPONSABILIDADE CIVIL, PENAL E ÉTICA. QUEBRA DE SIGILO POR JUSTA CAUSA}

O segredo médico é considerado por alguns como "a mais extraordinária reserva moral da medicina" (W. Lacerda Panasco) e no caso de doenças gravíssimas e com alta carga de estigma e preconceito mais do que nunca essa noção se impõe.

Em nosso país as regras sobre o segredo profissional estão previstas no Código Penal e no Código de Ética Médica. No Direito Civil o tema se coloca dentro dos direitos da personalidade, especialmente no direito ao segredo que faz parte do direito à intimidade e à vida privada, garantido pela própria Constituição Federal.

O Código Penal, de fundamental importância na matéria, determina em seu artigo 154: "Revelar a alguém, sem justa causa, segredo de que tem ciência em razão de função, ministério, ofício ou profissão, e cuja revelação possa produzir dano a outrem: Pena - detenção de três meses a um ano ou multa. § único: somente se procede mediante representação". Portanto, para a lei penal requisito fundamental da revelação do segredo é o dano que esse produziu a outrem.

Na responsabilidade civil o mesmo deve acontecer, ou seja, o médico que, quebrando ilegitimamente o sigilo (mesmo depois da morte), causar danos ao paciente (ou à sua família) deverá indenizá-lo. É preciso que a vítima do dano prove a culpa do profissional (comunicação injusta) e os preju- 
ízos morais e materiais (também cumulativamente, conforme a súmula 37 do STJ) efetivamente sofridos. Apesar de não haver regra expressa sobre o tema no Código Civil, está perfeitamente protegido o cliente pelas regras de toda sistemática da responsabilidade (em especial art. 159), pela jurisprudência, pela doutrina e evidentemente pela Constituição Federal. E havendo legítimo interesse econômico ou moral sempre haverá possibilidade do pedido de ressarcimento.

Dessa forma, poderá o médico que viola segredo profissional responder civil e penalmente (uma responsabilidade é independente da outra) e ainda sofrer sanções de caráter disciplinar previstas no Código de Ética Médica. De outro lado, o Código de Ética Médica vai fornecer os elementos que irão nortear os julgadores nessa matéria, como fonte informativa, pois não contém por si só a "carga de juridicidade" necessária à coação legal propriamente dita.

Também é necessário reiterar que a família do aidético, estando ele vivo ou morto, também poderá ser atingida pelo rompimento do sigilo. Nesse caso caberá aos familiares indenização por dano moral reflexo ou por ricochete.

Há hipóteses em que o médico não pode ser acusado de quebra de sigilo, pois tem a seu favor a "justa causa" para assim proceder, como, por exemplo, informar o cônjuge ou companheiro do doente, declaração da causa mortis nos atestados de óbito, etc.

Também está o médico obrigado (dever legal) a revelar o que sabe sobre o doente quando assim o exige um interesse maior. Quando o interesse individual e o da sociedade estão em jogo prefere o legislador sempre este último. É o caso da Aids, altamente contagiosa e catalogada entre as doenças de notificação compulsória. Segundo o Cremesp somente os portadores de Aids se colocam nessa obrigatoriedade. Os casos de pessoas que somente estão infectadas pelo vírus HIV não precisam ser comunicados. Vale ressaltar que notificação compulsória não significa publicidade, muito pelo contrário.

Sobre a ética médica nos casos de por- tadores do HIV/Aids há importante e esclarecedora norma do Conselho Federal de Medicina e que poderá servir de subsídio aos julgadores em caso de demandas contra médicos. Resolução CFM nº 1.359/ 92, principais pontos:

- o atendimento profissional a pacientes portadores do vírus da imunodeficiência humana é um imperativo moral da profissão médica, não podendo nenhum médico recusá-lo. Além disso, não se poderá alegar desconhecimento ou falta de condições técnicas para o caso de recusa de prestação de assistência;

- o sigilo profissional deve ser rigorosamente respeitado em relação aos pacientes com Aids. Este dispositivo aplica-se inclusive aos casos em que o paciente deseja que sua condição não seja revelada sequer aos familiares, persistindo a proibição de quebra de sigilo mesmo após a morte do paciente;

- a quebra de sigilo será permitida quando houver autorização expressa do paciente, ou por dever legal ou por justa causa;

- igualmente, o médico que presta seus serviços a empresa está proibido de revelar o diagnóstico de funcionário ou candidato a emprego, inclusive ao empregadore à seção de pessoal da empresa, cabendo-lhe informar, exclusivamente, quanto à capacidade ou não de exercer determinada função;

- é vedada a realização compulsória de sorologia para HIV, em especial como condição necessária a internamento hospitalar.

\section{NEXO CAUSAL E AVALIAÇÃO DAS CULPAS NOS CASOS EM QUE HOUVE CRIAÇÃO DE RISCO DE CONTAMINAÇÃO DE DOENÇA GRAVE. AS CONCAUSAS SUCESSIVAS}

A determinação do nexo causal, imprescindível na imputação da responsabilidade civil, nem sempre é fácil na prática. Cumpre ao lesado provar a relação certa e necessária entre a culpa (ou fato danoso, na teoria do risco) e o dano, sem a qual se tornará impossível o pedido de indenização. 
No ponto que nos interessa-as contaminações - às vezes se torna difícil identificar qual dos fatos foi a verdadeira causa do dano, principalmente, quando, devido às circunstâncias, várias hipóteses podem ser levantadas. Na verdade, estamos diante de "concausas" ou de "causalidade múltipla".

O grande problema que se coloca na prática é a existência de causas sucessivas sem conseguir-se determinar qual delas efetivamente foi a responsável pelo evento danoso ou mesmo se todas elas contribuíram para o desfecho fatal. Não se trata de discutirmos as teorias sobre o nexo causal e suas variantes mas mostrar que, diante do quadro de gravidade das infecções por vírus da Aids, temos que levar em consideração, sempre tendo em vista uma melhor proteção dos cidadãos, as várias concausas sucessivas. Em outras palavras, quando, através de cadeia de fatos danosos, que culminaram por levar a vítima a contrair Aids, devemos considerar todas as causas que criando riscos levaram ao final infeliz.

Podemos imaginar a situação em que determinada pessoa gravemente atropelada é obrigada a tomar várias transfusões de sangue vindo a contrair o vírus HIV. Quem deverá ser responsabilizado pela contaminação? O hospital ou o agente causador do atropelamento? Ou os dois conjuntamente, cada um respondendo por sua parte?

$\mathrm{Na}$ verdade, nenhum caso pode ser resolvido somente através da aplicação desta ou daquela doutrina jurídica abstratamente, mas sim através de exame concreto de todas as circunstâncias. Todavia, em princípio, a teoria da equivalência das condições vem "em socorro da vítima, tentando resolver, na prática, o problema da relação causal e tem o mérito da simplicidade" (19).

No caso do atropelado que acabou contraindo Aids, os dois agentes responderiam, pois toda condição que contribuiu para o resultado danoso constitui sua causa. A causa está em cada uma das condições. O autor do atropelamento expôs a vítima ao risco de contaminação e essa foi condição necessária (conditione sine qua non).

É preciso esclarecer que estamos tentando aplicar a idéia jurídica genérica de risco como sinônimo de perigo a que ficam expostas as pessoas ou coisas. Dessa forma, na cadeia de fatos que culminaram no dano, há a anterioridade de vários atos culposos ou até os que objetivamente podem gerar a responsabilidade. O problema está todo em provar a relação de causalidade entre cada um desses acontecimentos e o dano. Desde que provada, vai depender de cada hipótese a aplicação da teoria da culpa, do risco ou da presunção de culpa.

Dentro dessa filosofia protetora da parte mais fraca ou da parte mais exposta a riscos temos dois julgados franceses que merecem ser mencionados (20).

A primeira decisão vem do Tribunal de Versalhes (30/3/89), e trata-se de caso em que médico respondeu integralmente pela morte de paciente, que veio a falecer em decorrência de sangue contaminado com vírus HIV, depois de ser obrigado a tomar várias transfusões, tais os erros e culpas do cirurgião (extraiu a vesícula e ainda reoperou o paciente mais três vezes). Nesse caso foi aplicada a teoria da causalidade adequada, ou seja, depois de considerar-se todas as causas que concorreram para a morte, chegou-se à conclusão de que as causas aptas (adequadas) a levar o paciente à morte foram as várias operações seguidas que o enfraqueceram sensivelmente. Foram expurgadas as chamadas causas secundárias, como as transfusões contaminadas. O cirurgião foi culpado de criar o risco (perigo). Essa decisão foi por demais rigorosa contra o médico e só se explica pela tendência jurídica moderna de tratar com rigor os responsáveis quando a vida ou a saúde estão em jogo.

Também o Tribunal de Paris (7/7/89) considerou causador de acidente de trânsito como culpado de morte de vítima por Aids, tendo em vista que foi contaminada pelo vírus HIV por causa da necessidade de receber muito sangue no hospital, pois, inclusive, ficou provado que um dos doadores estava contaminado. A causa preponderante, ou seja, necessária e adequada da morte, foi considerada o acidente.

Se tais decisões tivessem se fundamentado na "equivalência das condições" teri- 
am, da mesma forma, punido os culpados e ao mesmo tempo sido mais justas. No Brasil temos notícia de caso semelhante ainda em juízo singular, que está sendo julgado nesse sentido.

Merece crítica decisão da $2^{\text {a }} \mathrm{C}$. do Tribunal de Justiça do Paraná (4/5/94) na qual foram absolvidos os médicos e o hospital por infecção hospitalar após cirurgia, pois foi dito que não ficou provado o nexo causal entre a conduta dos réus e o resultado lesivo. O dano decorreu, segundo a decisão, de condições predisponentes da autora: estágio avançado de doença varicosa, além de obesidade, o que, segundo o laudo, torna os obesos duas vezes mais suscetíveis a infecções (21).

Evidentemente, no caso acima relatado o estado da paciente pode ter favorecido a instalação da infecção, porém se os médicos já sabiam disso deveriam ter tomado o dobro de cuidados quanto a infecções ou operar em outro hospital. Todas as condições que levam ao dano têm que ser consideradas causas, inclusive até para diminuir a responsabilidade do culpado, como na concorrência de culpas.

Ao aplicar a teoria do efeito direto e imediato, prevista no artigo 1.060 do Código Civil, é evidente que o juiz também deverá examinar todas as circunstâncias concretas e as concausas sucessivas que chegaram a produzir o dano. Dentro da linha de nosso Código tem que ser levada em consideração, da mesma forma, a causa necessária das conseqüências nefastas. O grande problema que existe dentro do nosso sistema é o aparecimento da chamada causa estranha (de difícil conceituação), que pode levar à interrupção do nexo causal e ter efeito liberatório para os culpados.
21 Apud Miguel Kfouri Neto, Responsabilidade Civil do Me- dico, São Paulo, Revista dos Tribunais, 1996, p. 419.

\section{BIBLIOGRAFIA}

AMARANTE, Aparecida. Responsabilidade Civil por Dano à Honra. 2a ed. Belo Horizonte, Del Rey, 1994. AZEVEDO, Antonio Junqueira de. Negócio Jurídico e Declaração Negocial. São Paulo, 1986.

BARROS, Antonio Osório Leme de. Aids e Ética. Cremesp.

BIGI, José de Castro. "Dano Moral em Separação e Divórcio”, in RT 679/46, São Paulo, 1992.

D. MALICIER, A. Miras. La Responsabilité Médicale. Lyon, Alexandre La Cassagne, 1992.

FRANÇA, R. Limongi. “Aspectos Jurídicos da Aids”, in RT 66I/I3, 1990.

GONÇALVES, Carlos Roberto. Responsabilidade Civil. 5a ed. São Paulo, Saraiva, 1994.

Grupo pela Vidda. Direitos das Pessoas Vivendo com HIV e Aids, Ministério da Saúde, 1994.

KFOURI NETO, Miguel. Responsabilidade Civil do Médico. 2a ed. São Paulo, Revista dos Tribunais, 1996.

LEVI, Guido Carlos. Aids e Ética. Cremesp.

“Long Latency precedes overt seroconversion in sexually transmitted human immunodeficiency virus infection", in The Lancet, set./1987.

LOPEZ, Teresa Ancona. "Responsabilidade Civil dos Médicos”, in Yussef Said Cahali (coord.),

Responsabilidade Civil: Doutrina e Jurisprudência, 2ae ed. São Paulo, Saraiva, 1988.

MURIEL, Christine Santini. “Aspectos Jurídicos das Transfusões de Sangue”, in RT 706/30, São Paulo, 1994. PENNEAU, Jean. La Responsabilité du Médicien. Paris, Dalloz, 1992.

PEREIRA, Caio Mário da Silva. Responsabilidade Civil. 8ª ed. Rio de Janeiro, Forense, 1996.

SEVERO, Sérgio. Os Danos Extrapatrimoniais. São Paulo, Saraiva, 1996.

SOARES, Orlando. Responsabilidade Civil no Direito Civil Brasileiro, São Paulo, Forense, 1996.

TERCIER, Pierre. Le Nouveau Droit de la Personnalité. Zurique, Schulthness Polygraphischer, Verlag, 1984. THE EPIDEMIOLOGIC REVIEWS. Johns Hopkins University School of Hygiene and Public Health, vol. 15, no 2, 1993.

VARELLA, Drauzio, ESCALERIA, Narciso e VARELLA, Fernando. AIDS Hoje. $2^{\underline{a}}$ ed. São Paulo, Centro Educacional Objetivo. 